\title{
Foreign Policy Change in Brazil: Comparing Castelo Branco (1964-1967) and Fernando Collor (1990-1992)
}

\author{
Ítalo Beltrão Sposito \\ Institute of International Relations, University of São Paulo (IRI/USP), Brazil
}

\begin{abstract}
In this article, I intended to develop an analytical schema to analyze moments of redirection in Brazilian Foreign Policy. The schema encompasses the following logic: sources from national and international contexts may influence the domestic political arena, leading to the opening of a policy window and the rupture of stabilizers, which together may form a scenario prone to reform in terms of foreign guidelines. In this context, the decision makers may opt to promote a foreign policy change (FPC). To apply this model, we chose two administrations that are substantially different as to their international system and their political scope, even though both are considered by the Brazilian foreign policy literature as restructuration periods. By studying these administration's foreign policies, we tested the utility of this model and accomplished a comparative analysis seeking similarities amongst these chancing processes.
\end{abstract}

Keywords: Sources; stabilizers; change; foreign policy.

\section{Introduction}

The object of this article is a specific theme within Brazilian Foreign Policy (BFP),

1 the foreign policy change (FPC), which will be discussed by means of a compared analysis between two administrations: Humberto Alencar de Castelo Branco (19641967) and Fernando Collor de Mello (1990-1992). We set off from the perception that this phenomenon took place in both of the aforementioned administrations. Our objective is to identify how the FPC process took place by replicating an analytical framework specifically developed to analyze this process in countries with institutional and political frameworks similar to Brazil. Therefore, it will be possible to identify and to systematically 
discuss the influence of the independent variables (IV) on the research's dependent variable (DV), the FPC.

We also aim to find similarities as to the stance of the two presidents when they decided for a shift in foreign policy, and therefore analyze if there are patterns in the actions of the executive and the Ministry of External Relations (MER) during times of foreign policy redefinition. The objective is to analyze the change process - the implementation, its causes and conditions, primarily - by opposing the foreign policy of the analyzed administrations to the previous one, with little attention towards the subsequent administration (the FPC will always be analyzed in the transition between two executive mandates, even if the transition is not a necessary condition).

FPC is still an underexplored subject within the literature dealing with BFP and Foreign Policy Analysis (FPA). Domestically speaking, there is a predominance of paradigmatic studies and foreign policy history. In these, the focus lies on continuity and its causes, with no further investigations as to the motives and moments of rupture (Cervo and Bueno, 2002; Lima, 1994; Pinheiro, 2000 and 2004; Saraiva, 2003; Vizentini, 2008). In international terms, the literature on the matter has commonly argued for continuity and consensus as the adequate behavioral pattern, with a predominance of studies on continuity patterns instead of focusing on specific change scenarios (Gilpin, 1981 apud Rosati et al, 1994).

The choice behind these administrations is attributable to both being widely different periods - in regards to their historical and political domestic context, international system (IS) etc - with a relative consensus within the literature as being cases of FPC, even if discrepancies do exist as to the degree in such changes (Casarões, 2011; Cervo and Bueno, 2002; Lima, 1994; Pinheiro, 2000 and 2004; Vizentini, 2008).

The article unfolds in the following manner. In the next section there will be a theoretical discussion regarding the literature on FPA and BFP geared towards the explanation of the proposed analytical scheme used to analyze FPC cases. In the following two sections this theoretical framework is then applied to analyze the Castelo Branco and Fernando Collor administrations. In the fifth section the discussion will be centered on the occurrence of FPC in these administrations with basis on a checklist that enumerates the points which define the degrees of FPC within these processes. In the section after a comparison aims to find patterns to identify the main determinants and motives for the FPC; in it, there is also an attempt to discuss some possible contributions that this article may bring towards the specialized literature as well as its weaknesses and an agenda for future research. Lastly, some final considerations will be woven. 


\section{Theoretical Discussion}

Firstly, we believe it is important to underline that, since the focus is on the domestic political processes that results in foreign policy, the State will not be analyzed as a "blackbox" (Rynning and Guzzini, 2001). Within this perspective, foreign policy is treated as a public policy whose formulation and implementation are defined by decision-makers, taking into consideration domestic imperatives, although differentiated from others by having influence over and/or being influenced by issues connected with the IS (Pinheiro and Solomón, 2011).

A differentiation among the "phases" of foreign policy seems useful to us when discussing our object. According to Papadakis and Starr (1987) foreign policy can be conceptualized as: (1) a product (output), according to its substantive content; (2) as a process during which its development and implementation takes place; (3) as a behavior, which refers to the product implementation. Therefore, foreign policy may have different conceptual applications: (1) the set of ideas and values used by the State in order to legitimize its overseas activity based on a construct referred to as "national interest"; this in turn is fashioned by means of a (2) "complex process of interaction between many actors, differentially embedded in a wide range of different structures. Their interaction is a dynamic process, leading to the constant evolution of both actors and structures" (Hill, 2003, p. 28); and the results of this process are perceived as (3) "the sum of official external relations conducted by an independent actor in international relations" (p.3).

Since the article will analyze the process by which changes in foreign policy are developed it will be required to consider all of these stages: the project, the decision-making process, and the implementation. Firstly, it's important to analyze the new foreign policy project advocated by the Brazilian government given that both the analyzed governmental discourses argued towards the necessity of redirecting BFP. And the decision-making process is of an utmost importance since it deals directly with the dependent variable in this article, considering that the FPC is a result of the actions of actors with political capital within the domestic sphere. Lastly, based on an analysis of the Brazilian external behavior we can argue as to which are the main characteristics of the FPC, its effects on agents and structures related to BFP and on foreign policy itself (degree, range, period etc).

Thus, the FPC will be considered as a set of initiatives that aimed to establish a new international behavioral pattern for Brazil. The FPC does not necessarily have the desired effect nor the initially predicted duration since they usually occur at moments when a country does not have enough bargaining power to produce the aimed effects and/ or in moments when a political and economic crisis is in place, resulting in the need for 
emergency decisions - and these may also lead to future revisions of the previously made decisions (Gustavsson, 1999; Volgy and Schwarz, 1994).

\section{Methodology}

The chosen method was the method of agreement, which aims to analyze cases with different characteristics in the IV and with similar behavior to the DV (Mill, 1973 apud Van Evera, 1997). A qualitative comparison presumes a probabilistic causality (not necessarily deterministic) in that a set of conditions may increase the chances of a result or to predict its outcome. For an efficient comparative analysis to take place there is the need to follow a common conceptual framework and to deal with the problem of selection and judgment biases (Sartori, 1994). Therefore, an adequate analytical scheme was developed for cases of FPC in which similar causes and conditions are specified so that they may be systematically compared.

The analysis of the periods will be carried out by means of a replication of an analytical scheme with an "input-output" logic that relates the sources of the domestic and international environments with the foreign policy; the theoretical and methodological bases for the theoretical framework stem from studies on foreign policy change within the FPA literature.

The scheme was developed with the intent of answering the main questions concerning the DV: (1) What is a FPC? (2) How does it occur? What are the main sources of change and continuity (intervening independent variables)? (3) When? In which moments does this process have a higher chance of occurring? (4) Who? Which actors have the power to promote a FPC (intervening shaping variables)?

The operational and international logic between the variables follows the chain explained by Figure 1 below:

Figure 1. Chain of Variables

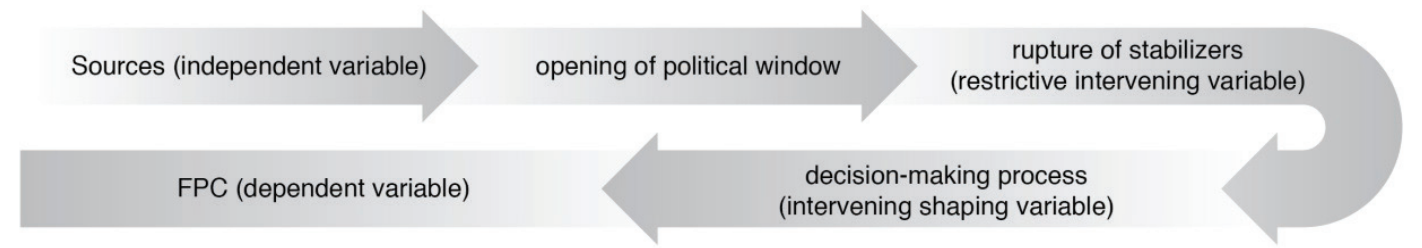

Source: Author's own. 
Generally speaking, the literature considers that a FPC will occur or be determined by the interaction between the independent and intervening variables. On the one hand, there are the stabilizers or restrictions, factors that influence the environment responsible for the formulation and implementation of foreign policy in favor of continuity (restrictive intervening variables). On the other hand, there are sources of change (independent variables), influenced by the IS and the domestic context, which could favor a FPC. A rupture of these stabilizers leads to an "opening" of a policy window - an exceptional moment that gives room for extraordinary political actions - that may be perceived by decision-makers as an inadequate foreign policy concerning the incentives of domestic and international sources, and thus, resulting in a FPC. The latter will only occur if so decided by the actors with the power to make such decisions, seen as intervening shaping variables, since they will be the ones responsible for reading the sources, taking advantage of the policy window, and defining the expected outcome. Even with this division, it is hard to delimit theses phases within the change process as well as to establish clear boundaries for the types of variables.

That being said, we pass on to point (1). The literature has already developed several change typologies, such as: (a) a distinction between adaptation and restructuration/ redirection, with the first being a more common change and the latter more radical one (Holsti, 1982); (b) a four degree change scale according to the depth of the implemented FPC (Hermann, 1990; Rosati, 1994).

Another analyzed factor is the duration period for the change, which, if it has a gradual nature, is closest to the adaptation type; if the change occurs quickly then there is more identification with the redirection cases (Volgy and Schwarz, 1994). The temporal issue at stake here is more closely related to the process of change itself - the sense of urgency would facilitate the process - and not with the duration of the FPC effects.

Furthermore, the authors also call attention to: the importance of the FPC to cover multiple thematic fields in order for it to be more significant (Volgy and Schwarz, 1994); to the possible influences of the process on bureaucracies specialized in foreign policy (Kleystra and Meyer, 2001); to the possibility of a change in posture towards the hegemon (Hagan, 1989).

Regarding point (2), the main concepts discussed by the literature are the sources and the stabilizers. The sources are factors related to the IS and to domestic politics (fundamental structural conditions), which may encourage a FPC; they are the independent variables within the scheme (Goldmann, 1988; Gustavsson, 1999; Hermann, 1990). Niklasson (2006) uses the term "change promoter": "any factor within or outside agent A that, while stabilizers are held constant, increases the likelihood that A will abandon, or considerably modify, policy P." (p. 45). 
As for the stabilizers, they appear as barriers to the reading of sources by the decision-makers, affecting these actors' sensitivity level towards their surroundings; the restrictive intervening variables are the ones that affect: a) the probability that an event (source) will indeed lead to a redirection; b) the extent to which a change process will continue, resulting in a FPC (Goldmann, 1988; Volgy and Schwarz, 1994).

The change processes would have a greater chance of occurring during certain moments (3), conceptualized by the specialized literature as the policy window, the moment in which the stabilizers would be "ruptured", increasing the decision-makers' sensibility towards the sources.

The idea of a policy window was taken from the literature concerning processes of political reform, called space windows by Kingdon (1984 apud Gustavsson, 1999), which refers to periods in which political actors take advantage of a specific conjuncture, so as to insert their political proposals in the agenda, and to persuade other actors to support a certain solution in order to overcome the political inadequacy in the surrounding conditions. Policy windows are moments in which the political costs for change became smaller, making it so that the actors become more interested in carrying out the desired reforms as quickly as possible.

Such moments would have the following characteristics: (a) low level of commitment by the new administration towards the previous foreign policy; (b) interdependence between foreign policy and other public policies; (c) economic or political crisis (Gustavsson, 1999); (d) change in the political regime - here defined and classified in a similar manner as to Hagan (1989) -, as well as any change in the main body of political leadership, the group who controls the central political structures in the national government.

Actors with enough power to implement a FPC would be those that are members of the Ultimate Decision Unit (UDU) (4), agents with the ability to compromise the government's resources with no possibility of a reversal by part of other actors (Hermann, 1990). For the Brazilian case the main actors in foreign policy are the President and the MER. For this reason, the presidential interest in themes concerning foreign policy can be determinant in the choice of the international guidelines for a governmental administration (Lima, 1994), considering that presidential diplomacy is strongly tied to domestic interests (Danese, 1999). Therefore, change would depend on the decision-makers and would have a greater chance of occurring if there was interest and involvement by part of the leader and if the problem was seen as essential for the maintenance of the regime (Hermann et al, 2001). Based on this discussion, a checklist was designed with the objective of classifying the government administrations among the degrees of FPC; the more points that are complied with, the more drastic the change. The points are as follow: (I) multidimensionality of the themes affected by change; (II) new normative bases for foreign policy; (III) 
a process that took place within a short time span; (IV) change of stance towards the United States (USA); (V) effects on the bureaucratic structure. Therefore, a FPC could merely be an adaptation of a country's international behavior, but the larger the number and degree in meeting the points highlighted above, the more drastic the FPC will be. The words and quoted concepts highlighted in italic during the governmental analyses refer to classifications and points in the analytical scheme. A general visualization can be seen in figure 2, which summarizes the "input-output" scheme.

Figure 2. Input-output analytical schema

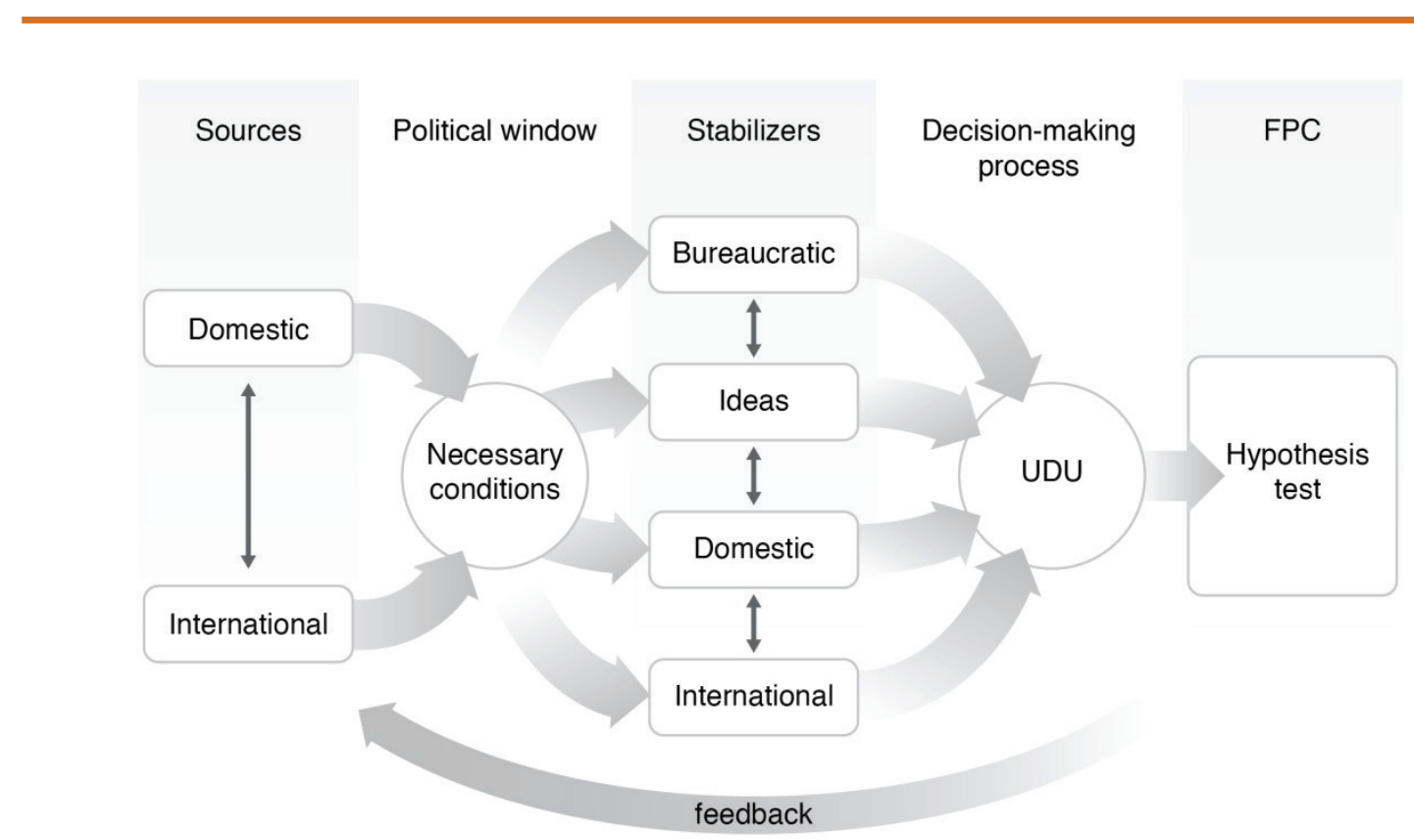

Source: Author's own.

\section{Castelo Branco Administration}

In the following section we will carry out an analysis of the Castelo Branco administration (1964-1967), according to the previously proposed scheme. We will argue that the sources indicated a need for change and ongoing circumstances led to the "rupture" of stabilizers, therefore ensuring legitimacy and justification for the deployment of a new "national project" with direct consequences to foreign policy. Topics (1) and (2) deal with the domestic policy sources (political regime support), points (3) and (4) deal with the domestic economic sources (economic conditions and public-private relations), points (5) and (6) deal with international political sources (external pressure and institutional apparatus) and points (7) and (8) with international economic sources (economic and financial 
systems). The following symbolize the stabilizers: (i) bureaucratic (rules and standard norms), (ii) ideas (institutional and political), (iii) domestic (political fragmentation and presence of the opposition) and (iv) international (system structure and stability). Each one of these points is part of a structure within the proposed analytical scheme to analyze the sources, conditions and resultants of the FPC process.

(1) With the opposing forces abolished from the political system, the regime established by the 1964 coup d'état had sufficient domestic political support to develop its national project. Generally speaking, the political arena was divided into two major groups (Martins Filho, 1996; Simões, 2010; Vizentini, 1998): (a) liberal or legalistic sector (the "castelistas") who advocated for a short term regime in order to reform the State and to deter the communist threat; (b) the hardliners, comprised of supporters of a military and economic nationalism and who pressured for the continuity of the military regime. Within this system, the rival political group advocated for a radicalization of the regime instead of being an opposing force (iii). The state of emergency measures carried out by the Institutional Act (09/04/1964) assured the president the mechanisms to "nullify" forces allied with the previous regime. The effective number of parties (defined by $1 /(1-F)$, in which $\mathrm{F}=$ party fragmentation index) was 1 in 1964 and 1965, rising to 1,782 in 1966 and 1967 (Alvarez et al, 2003), thus indicating a low political fragmentation.

This political scenario also allowed for the regime to implement changes within the MER, with consequent effects on its institutional ideology (ii). The first post-1964 Chancellor, Vasco Leitão da Cunha, managed to establish an internal committee to evaluate the employees' relation with the old regime, thus avoiding the establishment of a General Information Committee (GIC) - headed by a military member - which resulted in only four compulsory retirements, a laughable number when compared to other ministries (Almeida, 2008). The counterpart would be the abandonment of previous foreign policy guidelines (Independent Foreign Policy - IFP').

Changes were introduced to the MER's bureaucratic structure (i). One could say that a process occurred in which more power was granted to the Ministry on subjects concerning commercial policy (Decree No. 50.332 from 10/03/1961 and Law No 4.669 from 08/07/1965), and following the military regime's objective in conferring "technical competence" to the bureaucracies. In a complementary way, by means of Law $\mathrm{N}^{\circ} 4.415$ (24/09/1964), the regime changed its promotion criteria, replacing the seniority item by

1 Central premises: seeking to diversify commercial partners, detailing of ideological issues, independent posture, emphasis on South-South relations (Cervo and Bueno, 2002), and "[...] had as its principles the expansion of Brazilian exports to any country, including the socialists, the defense of international law, self-denomination and non-intervention [...]" (Vizentini, 1998, p.22). 
merit, a possible ploy to replace an objective criteria (years of career) for a subjective one (merit).

In the security field, the Planning and Study Group (PSG), established by Decree $\mathrm{N}^{\mathrm{O}}$ 46.804 (11/09/1959), became an institutional means for decision-making in international politics and an important channel for delegating "several clearly executive responsibilities [...] to the Secretary-General of the National Security Council (SG/NSC) (CRUZ, 2009, p. 282).

The Itamaraty also began to operate in the field of security through the Center of Foreign Information (CIEx), founded by Pio Correa in 1966. The center was initially founded to monitor and investigate Leonel Brizola's actions in Uruguay, but was later extended to other several countries due to its success and the allocation of its founder to the General Secretariat of Foreign Policy in the MER (Cruz, 2009).

(2) The coup d'état also led to a change in the elite's social composition. The group that legitimized the overthrown regime supported a national capitalist development project, primarily composed by the autonomous national bourgeoisie, urban middle-class, popular masses and constitutionalist military personnel. The regime change led to a policy direction (including foreign policy) towards the contemplation of other societal sectors which supported the coup: the bourgeoisie associated with international capital, especially with American capital, the "[...] more modern sectors of the urban middle-class [...] the military and civil bureaucratic elites who controlled Brazil's State apparatus" (Martins, 1975b, p. 19).

(3) The economic conditions presented a problematic situation, conferring legitimacy to the changes. The inflation rate displayed a tendency towards growth: already at a very high rate in 1962 (51,84\%), it increased in 1963 (70,08\%), and reached its peak in 1964 (91,88\%) (Alvarez et al, 2003). The variation in the per capita income also expresses a deterioration trajectory, with a decline in 1963 (-2,3\%), low growth in 1964 (0,4\%), and a new downturn in 1965 (-0,5\%) (Reis, 2003).

(4) As for the institutional conditions of the domestic economic relations, a large portion of the measures undertaken by the team led by Roberto Campos, Minister of Planning and the organizer behind the Governmental Economic Plan of Action (PAEG), aimed to reestablish good relations with international investors. For this purpose, the new regime founded a series of financial institutions, aiming to establish "rational and technical-scientific criteria" and to change the relationship between the State and the financial sector: Law N ${ }^{\circ} 4.595 / 1964$ founded the National Monetary Council and the Central Bank of Brazil, both designed to independently conduct the monetary policy; Law $\mathrm{N}^{\circ} 4.728 / 1965$ reformed the capital market and redefined the operational rules for financial agents (Dreifuss, 1981). 
(5) The IS structure in 1964 was considered to be bipolar and was not undergoing any structural changes. The strain in the USA-USSR relations had not yet begun and thus, we classify the IS as "static bipolar" (iv) - dominated by two superpowers and structurally stable. Therefore, even if the initial hypothesis states that a static bipolar IS could be a restriction to a FPC, the approximation policy towards the US seems to be a choice "encouraged" by this source, since there was pressure for the weaker countries to align themselves with one of the Cold War blocks.

(6) Within this IS the international organizations (IO) would have the role of legitimizing this structure. The leadership of both superpowers made it hard to adopt a neutral or independent position and the IO functioned as communication channel between both parts so as to promote this coercion; these institutions did not adopt coercive postures themselves, but perpetuated the prevailing order (Cox, 1993).

There was also a regional "wave" of foreign policy readjustment (iv). Regime change processes occurred in some countries within the continent (such as Argentina in 1962, and the Dominican Republic, Guatemala and Honduras in 1963) in similar molds as to Brazil and with similar consequences to domestic, foreign and economic policies: rise of US backed authoritarian regimes, alliance with international financial groups and a domestic political base within the traditional domestic elites (Ayerbe, 1992).

(7) The international economic indicators also pointed towards the need for change. In the initial period of the new regime, the Brazilian economy was walking in the world's opposite direction; the world growth rate increased 3,15\% in 1962, peaking at 5,39\% in 1964 and once again decelerating in 1967, but still maintaining a 2,59\% growth (Alvarez et al, 2003).

(8) The international economic institutional conditions became more favorable after the reforms in the economic landmarks - as referred in (4). Consequently, the financial help in the regime's early moments grew once again and reverted a tendency: from US $\$ 15,1$ million in 1964 to US\$122,1 million in 1965 , and US\$129,3 million in 1966 . The guarantee of foreign company rights also led to a rise in international investments in the country, with an increase in the period ranging from 1963 to 1968 of US\$ 169 million to US\$ 481 million (Ayerbe, 1992).

According to the proposed scheme, such sources would have led to a FPC prone scenario - the policy window. This conjuncture is comprised by the jointure of the following points.

(a) Low government commitment to the previous administration's foreign policy. The 1964 MER report shows that: "one of the first steps taken by the 'Revolution Government' was to verify the sinuous course which [...] strayed from our diplomatic tradition and escaped the basic principles of our historical formation" (MER, 1964: 3 - author's quotation 
marks). The commitment of the new regime to the previous foreign policy was extremely low since its legitimacy was tied to the anticommunist struggle.

(b) In the early days of the military regime, there was a very close relation between the adopted external policy and other policies that comprised the "national project", partially developed in discussions within the Superior War School (SWC - ESG in Portuguese). Some important measures undertaken by the Castelo administration had an "esguiana" inspiration, such as: the foundation of the National Information Service (NIF) by Decree-Law No 4.341(13/061964); Decree-Law No 314/1967 concerning the National Security Law (NSL); Decree-Law No 200/1967 concerning Administrative Reform (Miyamoto and Gonçalves, 1993). Castelo Branco himself expressed, during a speech when handing out the diplomas for the Diplomatic Career (31/07/1964), the existing correlation between domestic and external policy (MER, 1966).

(c) One of the main characteristics of the policy window, as raised by the literature on FPA, refers to the crisis scenario. In the domestic sphere, Brazil was undergoing political and economic crises (points argued within this section).

(d) Besides the policy window category, another important factor is the regime change. In the analyzed case, the change in the regime happened by extra-constitutional mechanisms. According to Hagan's typology (1989), which classifies regime changes in five gradations, change would be considered to be more radical ("type 5") when there is a replacement of the group in power by another group with an opposite political vision and by means of a revolution or coup d'état.

\section{Fernando Collor Administration}

In the following section the Collor administration will be analyzed by following the same logic as the previous section.

(1) The 1998 Constitution gave broad powers to the President in comparison with the Legislative Power, a condition that would have been enough in order to implement the changes discussed below, even if without broad domestic political power (the president formed a minority coalition). The "National Reconstruction Project" implementation, present in his Inaugural Speech (Collor, 1990), was only made possible since Brazil has, since 1988, one of the highest rates of concentration of power in the Executive, with: power to veto legislation approved in Congress; exclusive power to issue decrees; exclusivity to propose legislation on certain issues (Brasil, 1988).

Therefore, the fragmentation of the political system (iii) was not a greater obstacle to the process of State reform or for a trade liberalization aimed at competitive insertion 
within the international economy, which doesn't mean that Congress played a role in this process.

(2) Due to changes in the economic power of the business elites there was a change in the elite's social composition and beliefs resulting in a loss of bargaining power by part of the unions and in an apparent consensus by the elites concerning the need for market reforms. Besides, the process of changes in ideas and values (ii) was also intensified by the exhaustion of the State-developmentalism model, associated with the military regime and with the 1980s economic crisis (Armijo and Faucher, 2002). The same happened with the political elite, who began a process of trade liberalization in 1988 by reducing the number of banned import items from 2400 to 1200 and with a process of gradually reducing customs fees in 1987 (Ricupero and Didonet, 1995 apud Guimarães, 2005).

(3) As for the domestic economic sources, the scenario presented several crisis indicators. In 1988 and 1989 the external debt reached the values of US\$ 102.555 and US\$ 99.284 million (Cerqueira, 1997). The variation in the Gross Domestic Product (GDP), which had once reached a growth of almost $8 \%$ in 1986, began a downwards tendency during the following years: 3,6\% (1987); -0,1\% (1988); 3,3\% (1989); -4,3\% (1990). Inflation, the main Brazilian concern in the early years of the 1990 decade, presented frightening numbers: 147\% (1986); 228\% (1987); 629\% (1988); 1430\% (1989); 2947\% (1990) (World Bank, on line).

(4) The institutional conditions of the relations between economic groups and the State also changed. The reforms carried out by Collor aimed to reestablish the trust of international investors and to obtain better negotiation conditions with creditors. While still early in the mandate, the president used Provisory Measures (PM) to initiate the reforms in his "National Reconstruction Project" (COLLOR, 1990). Provisory Measures 145 and 158 (Laws 8.016/90 and 8.032/90) restructured taxation rules for the import and export of goods; the PM 151, 155 and 157 (Laws 8.029/90, 8.031/90 and 8.018/90) abolished agencies of the federal public administration and started the privatization process; PM 162,168 and their "reissues" 172,180 and 184 reformed the conditions of the operation in the financial market and introduced the Cruzeiro.

The same legislative powers were also used to promote changes in the MER's structure (i). Decree No 99.261 (23/05/1990) instituted a change in the House's organization, dividing the General Secretariat in three instances. According to an interview given by Francisco Rezek (Collor's first Chancellor) to Casarões (2011): "the tripartition would then serve to avoid a concentration of power [...] which could [...] reduce the president's control over the ministry's structure" (p. 160). PM 150 changed the rules concerning retirement and career promotion. 
Itamaraty's role in defining the BFP during the Collor Administration is a matter of controversy. Batista (1993), for example, consigns the FPC process to the president, arguing that the MER had no participation. Arbilla (2000) considered that the elimination of the Secretary General of Foreign Affairs position and the adoption of a model of "imperial presidentialism" by Collor led to a breakage of consensus within the diplomatic corporation and to "Itamaraty's marginalization", in the BFP's definition. Conversely, Celso Amorim (1997) asserts that the MER had a counterweight role and advocated for thriftier negotiations in order to obtain concessions as an answer to the Brazilian trade openness. Ambassador Flecha de Lima, however, considers that there were two distinct groups in the FPC period: liberal and nationalists, being that the former supported Collor's national project (Casarões, 2011). Moreira (2001 apud Casarões, 2011) notes that the MER was a resistance focus to changes, advocating for a gradual opening, a position similar to the one defended by Celso Amorim.

We consider that the Itamaraty sought to act so that the FPC would be less radical and more gradual, while trying to bring its own foreign policy project to the foreground. The MER's exclusion argument in defining foreign policy seems less plausible when we consider the historical agency of this organ. The MER adaption process to the conditions imposed by Collor may have resulted in the alteration of its institutional ideology (ii).

(5) The IS structure was undergoing a transition period, which could mean a favorable scenario for a FPC. It would be the ideal moment to take advantage of the end of a rigid bipolar system and of the structural transition period and readjust the external agenda. The most "natural" path would be to follow the agenda of whichever world leader emerged at the end of the Cold War. In Latin America the "neoliberal reforms" were pervasively adopted, save for the particularities adopted by each country during their liberalization process (iv).

(6) At the top of the IO's agenda was the commerce negotiations and the "new issues" (copyrights, human rights and the environment). In these areas there was strong foreign pressure concerning Brazil's behavior (iv). On the environmental issue, the President sought to build a positive image of the country by claiming that development would no longer be tied to pollution (in a speech at the XIV General Assembly of the United Nations). On the human rights issue, the country participated in the 1990 World Summit for Children and later sanctioned the Child and Adolescent Statute (07/1990); the President also signed an act to guarantee the Yanomamis their right to an area of 35 thousand square miles (MER, 1992). These initiatives represented a new Brazilian stance in face of international pressure, considering that Sarney argued that industrial progress was tied to pollution and faced harsh international pressure in regards to the indigenous issue during his administration (Prado and Miyamoto, 2010). 
(7) International economic sources showed that the Brazilian economy followed the world tendency during this period, but with worse indicators due to inflation and external debt. The world GDP per capita presented the following variations: 1,5\% (1986); 1,7\% (1987); 2,8\% (1988); 2\% (1989); 1,2\% (1990); -0,6\% (1991); 0,6\% (1992) (World Bank, online).

In addition, the Prime-rate (American agency) international interest rates continued to grow, making it even more difficult to pay off the external debt (Cerqueira, 1997).

(8) The economic institutional conditions also directed Brazil towards change. In 1988, the Mid-term review (negotiation stage of Uruguay Round, which took place in Montreal) introduced the Trade Policy Reviews, an instrument to increase the transparency of Member-States with the objective of impeding "free-riders" (Brazil being considered one of them) and forcing members to implement structural reforms in their domestic spheres (World Trade Organization, on line). Additionally, there was also pressure from the IMF for a readjustment of the economic policy according to the new neoliberal model (Batista, 1994).

As for the policy window,

(a) the presidential speeches demonstrated a low governmental commitment to the previous administration's foreign policy. Ever since the electoral period, Collor had plans to change the foreign policy course. In his inaugural speech he stressed the need for foreign policy "to answer to the moment of affirmation of the popular will, which - urgently - demands for the modernization of Brazil [...] interdependence demands that every government act be a permanent combination of internal and external variables" (Collor, 1990: 20).

The president also advocated that BFP should "reflect the general conviction that this country wants to change, and quickly do so" (MRE, 1990. p.7). His intention to change the third world profile, to update the international agenda and to improve relations with the United States (Hirst and Pinheiro, 1995), shows that the President did not wish to continue the previous government's foreign policy, identified with the globalist paradigm.

(b) There was a strong link between foreign policy and other public policies. The link between the domestic and foreign spheres was based on a neoliberal ideal, which proposed to decrease the role of the State in the economy in order to overcome the ongoing crisis since the 1980s. Therefore, the president took measures in the domestic sphere so as to increase credibility in the eyes of external investors and creditors: financial-economic stability, exchange liberalization, end of subsidies and development of a new legislation for the fiscal, property and administrative spheres (Mello, 2000).

(c) The domestic scenario was one of crisis. Besides the poor economic indicators - already shown in this article - the political leadership also endured a legitimacy crisis. 
After the failure of the diretas já (popular movement for presidential direct elections) the indirect election of Tancredo Neves had an important political meaning, but his death before he could take office resulted in low political legitimacy for the new leader (vice-president Sarney) (Prado and Miyamoto, 2010). Within this scenario, the political legitimacy for the first democratically elected president after 20 years depended directly on his administration's economic results.

(d) The regime change, despite having occurred within the rules established by the 1988 Constitution, represented the first direct presidential election in Brazil after a lengthy period marked by a closed regime. The most important impact was the replacement of the group in power and the removal of a major portion of the military personnel holding executive positions. If we consider Hagan's typology (1989) with its 5 types of regime change, the Collor Administration transition could be characterized as "type 4" - the second most drastic degree of transition among political groups in power - since there was an almost complete replacement of the group in power without, however, the occurrence of a coup d'état.

\section{Argument and Checklist}

After the analysis of each one of these periods, the checklist items, which form the basis to determine the FPC levels, will be discussed.

(I) Multidimensional change. In both cases there was a proposal for a change in the "national project", with an impact on several areas.

During the Castelo administration the following areas were affected: a) security, national security was replaced by hemispheric security, with the instrumentalization of the hemispheric defense thesis as protection from the communist infiltration and relativization of the autonomy paradigm (Garcia, 1997); b) economy, laws that altered economic regulations aimed to attract international investments and loans, replacing the previous administration's nationalist model; c) regional policy sought to become the United States preferred ally and thus conferring a leadership position to Brazil in the southern part of the continent (Miyamoto and Gonçalves, 1993); d) reading of the IS; based on the EastWest division, as opposed to North-South, more prominent in the previous administration (Lima, 1994).

Collor's political project also encompassed a change in several thematic areas as well as priorities in the Brazilian international agenda. The inclusion of issues such as the environment, human rights, and the abdication of nuclear weapons meant a reconstruction and reorganization of foreign priorities. Additionally, there were changes in the areas of: 
commercial policy, science and technology and security (nuclear weapons) (Cruz et al, 1993).

(II) Conceptual change. The process was steeper with Castelo, who redefined the concepts for autonomy and sovereignty, adapting them to an idea of collective security - a model of shared sovereignty thought to be more adequate to stop the communist advance within the region. There were changes in the concept of non-intervention and self-determination, making them only applicable to "free nations" - see here Brazil's support to the intervention in the Dominican Republic (DR) at the OAS and to Portugal's colonialist policy at the UN, both justified by the argument that communist forces within these countries (DR and Portuguese colonies) were undermining the self-determination of its populace.

This posture represented a change to Jânio's administration, who refrained to vote in favor of Portugal in issues concerning the African conflict (Martins, 1975). Moreover, generally speaking, the globalist paradigm was replaced by Americanism (Viana, 1975).

Collor primarily used the concepts of "modernization", "change" and "international inclusion". The first one was coupled with changes in the economy by means of privatization and economic opening as well as the idea of "leading Brazil towards the first world" through a "complete overhaul of Brazilian politics" (Collor, 1990). However, it would not be correct to say there was an abandonment of the BFP's conceptual basis, since the principles for Brazilian international relations were institutionalized by the 1988 Constitution. Arbilla (2000) considers that the conceptual bases for foreign policy after the end of the Cold War were only established after the ascension of Celso Lafer. The early stage of Collor's administration, however, could be seen as a transition period within BFP's conceptual outline, during which the president took advantage of a "void" in the BFP's conceptual framework so as to insert concepts that would become constant in his electoral speeches.

(III) Timeframe. In both administrations, measures that aimed for a FPC were taken right at the beginning of the mandates. Castello presented the basis for his foreign policy as early as his famous speech at the MER, in 31/07/1964. The mandate revocation processes and replacement of important offices also occurred rapidly. The concern towards communists also appears as early as the first letter by Castelo to the MER, according to Viana (1975).

During the Collor administration, the process to change the Brazilian development model had already began during the Sarney mandate with the introduction of an economic liberalization. However, Collor gave continuity and further developed the process; besides, "swiftness" was one of the marks for the changes implemented by the president. Together with Rezek, it justified the need to promoted changes and legitimized such actions with his electoral-political capital. 
(IV) Distance level towards the hegemon. Castelo promoted a rapprochement towards the US, made explicit by his support to intervene in the DR, and his advocacy for creating the Inter-American Peace Force as well as defending the American anti-communist policies. According to a quantitative analysis by Hagan (1989), Brazil moved from a "moderately anti-US" stance to a "moderately pro-US" (respectively, 2/5 and 4/5 in the author's scale), which illustrates a new type of behavior for Brazil in the United Nations General Assembly (UNGA). Counter intuitively, Amorim Neto (2011) did not find a convergence increase in regards to the IFP period (measured by the average coincidence of votes among Brazil and the US in the UNGA - variable with a scale from 0 to 1), with the military administration being inferior $(0,61)$ to Jango's $(0,64)$. Even so, the author indicates a significant increase in the concordance of issues concerning policy and security, with an increase from 0,63 to 0,71 . An investigation in the author's data would be necessary so as to identify the reason behind such discrepant results - unfortunately, none of the two databases are available online for replication.

In a very similar manner, one of the main objectives behind Collor's foreign policy was to remove the tensions in the bilateral relations with the US (Hirst and Pinheiro, 1995). The adhesion to reforms encouraged by the hegemon was already an important step towards the removal of frictions and a bilateral rapprochement. In the UNGA voting, Amorim Neto (2011) pointed towards a decrease in the US-Brazil convergence, reaching an average index of 0,14 during the "collorida" ${ }^{2}$ administration. Also for this reason, and differently to some authors (Batista, 1993; Cervo and Bueno, 2002; Mello, 2000), we do not consider his external policy to be an alignment with the US.

(V) Changes in the bureaucratic structure. Firstly, Castelo Branco altered the role for the Minister of State. The last Minister during the Goulart Administration was João Augusto de Araújo Castro (1963-1964), closely identified with the IFP and was alongside Jango during the controversial special mission to Moscow and Beijing (1961). The most memorable episode during his time in office as Minister was his "Three Ds" speech at the UNGA (Lamarão, 2007). With Vasco Leitão da Cunha, however, there was the promotion of reforms, such as: change in promotion criteria; substitution of overseas representatives; coordinating the "witch hunt" in the MER. These projects outline Vasco's administrative and managerial profile as opposed to Araújo's role as a foreign policy formulator.

Secondly, the reforms reached/attained the division of labor among ministries and the portfolio of tasks performed by the Itamaraty. With Castelo, the change in the MER's role occurred by means of a new structure in the Propaganda and Commercial Expansion Services (SERPRO) and the MER's exclusivity in Brazil's overseas commercial promotion.

Translator's note: Here we find the use of a wordplay with the Portuguese word "colorida" (colorful) and a reference to Fernando Collor. 
On the one hand, the inclusion of SG/CSN as a new decision-making body for security and military inclusion in diplomatic missions represented a loss of institutional power. On the other hand, the Ministry also went on to act in the security area with the CIEx. These new measures meant for an increased importance of the Itamaraty within the federal structure.

With Collor, it is also possible to notice a change in the minister's role. Sarney's last Chancellor, Abreu Sodré, was appointed to accommodate political interests and to establish a governing coalition, with little influence in the House; as a result, the General-Secretary Paulo Tarso assumed the role of Chancellor (Casarões, 2011). As for Rezek's indication - a name coming from outside the corporation and who went on to defend Collor's foreign project policy - could have represented an "instrumentalization" by the minister on the part of President so as to gather support within the house for his already defined project. In the division of labor among departments and portfolio of tasks performed by the ministry, the federal administration reform, by means of the PM 150, had a considerable effect. The dismemberment of the General Secretariat led to a new division of labor, while the change in retirement laws led to a new personnel configuration. As for the establishment of the Latin American Integration Department within the MER, it represented the pursuit for maintaining competence in a specific area and to oppose the recently founded Extraordinary Ministry for Latin American Integration Affairs.

Lastly, as for the importance of the ministry in the federal structure, the last relevant change indicator for the MER in face of the other ministries was the transference of the international political and economic competences to the Ministry of Finance, Economy and Planning (MFEP). However, it is difficult to pinpoint if this meant a significant change in the Itamaraty's importance vis-à-vis other bureaucratic agencies. According to Amorim (2003), the MER had to act in order to ensure its competence in some areas, such as regional integration policy.

During the Castelo Branco administration, the FPC "fulfilled" practically all points raised by our qualitative analysis. This leads us to classify the analyzed FPC as a change in international orientation (Hermann, 1990) or restructuration (Rosati, 1994); the most extreme in the authors' four degree change scale. As for Collor, we consider it to be more suitable - since some points in our scheme were not contemplated and some changes had begun during the Sarney administration - to classify it as a change of problem or objective (Hermann, 1990), or reform (Rosati, 1994) - the third among the four FPC levels proposed by the authors. 


\section{Comparison in Search of Patterns}

In this section a comparative analysis will be developed between the two administrations in order to identify patterns among the analyzed situations, and which could indicate towards some of this article's possible contributions to the specialized literature.

Firstly, we identified the importance of structural shocks or exceptional moments for the promotion of a broad change project, factors related to a crisis - discussed alongside the policy window concept. Even though the FPC literature has already argued for the existence of a FPC in the analyzed administrations, an analysis had not yet been carried out with a specific methodology so as to base its argumentation; it merely stressed some signs of change (Cervo and Bueno, 2002; Lima, 1994; Pinheiro, 2000; Saraiva, 2003; Vizentini, 2008). The analytical framework is also a contribution in itself, since it may be used to analyze other FPC situations in Brazil or in countries with similar political systems.

Secondly, we considered that both the domestic and international contexts were of utmost importance for the change processes. At the same time, we consider that during the Castelo Branco Administration, domestic issues had more weight, while international factors had more weight during the Fernando Collor Administration, as pointed out by Flávia Mello (2000). However, it is not possible to prove that there was in fact a difference in weight for the internal and external contexts concerning the FPC.

The larger weight to the domestic sphere during the Castelo administration would result from a more recent and radical political rupture, while the international scenario at the time was not undergoing drastic changes. For Collor, the most recent and radical change took place in the international sphere, which was undergoing a transition period between two types of systems. Internally, the change resultant from the redemocratization was a more gradual process, with a similar effect on the FPC.

It is equally dangerous to claim that the FPC would have been less radical for these reasons; for such, it would be necessary to compare a larger number of cases. A valid argument is that the extralegal mechanisms, used for the complete replacement of the agents in power of the State, would be justifiable only if it also resulted in a turnaround in several political areas. For Collor, in spite of the change being announced in his national project, a failure in following through the plan would not undermine the legitimacy of his administration in such a determinant manner. The development of more detailed and conceptually richer change scales is another point in which the literature needs to advance.

Thirdly, the analyzed periods also represented substantial changes in structure, roles, tasks, and in the Itamaraty's areas of operation and in the Chancellor's function. Our interpretation is that these changes were political maneuvers so as to guarantee the success of the FPC process, that is, the presidents acted so as to diminish the MER's influence in 
issues concerning foreign policy at the same time in which it increased its own influence, even if that did not mean excluding the ministry from decisions. The discrepancy between foreign policy on the one hand, and national and international environmental changes on the other, shows that sometimes the bureaucratic agencies - identified with pattern continuity and institutionalization - do not adapt in the same velocity as the domestic political game, which would explain the direct actions by the president so as to promote the changes in foreign policy.

Fourth, while we suggested that the head of government had an essential role in the FPC we did not disregard the importance of other actors. The arguments are those already presented by the literature: the president's interest is determinant in the MER's relative autonomy in defining the foreign policy (Lima, 1994); a leader will opt for a redirection if there is interest and an active involvement in foreign policy and if the issue is considered by him to be essential to the maintenance of the regime (Hermann, 1981; Hermann et al, 2001). Therefore, the presidents used their office authority so as to legitimize their innovative projects for foreign policy: Castelo Branco justified the need for a FPC through society's support towards his government and to reestablish the political order and to ward off the "communist threat"; Fernando Collor relied on his electoral-political capital and based the legitimacy of his modernizing project by means of the population's demands for new directions for Brazil. Furthermore, the crisis scenario ensured greater decision-making power to the leaders.

Nevertheless, we do not consider the "predominant leader" concept by Hermann and Hermann (1989) to be adequate in order to describe the decision-making structure of these administrations due to the weight this category infers to the actor - decision as the result of the leader's individual choice -, even if the authors' definition states the importance of the leader's sensibility towards the political context for determining the outcomes and results.

In the studied cases, a more adequate theoretical framework to analyze the problem should include other relevant actor involved in foreign policy formulation and execution. One suggestion would be a structure that could allocate the president at the top of the decision-making structure at the same time in which the Legislative and the bureaucracies could respectively influence the decisions, remodeling the president's draft laws and negotiating deals, or approaching the final result to the political ideas defended by these institutions.

In both situations there is a pattern in the president's posture which led to an implementation of a different foreign policy model, but we do not consider, however, that this meant an exclusion of the Itamaraty from foreign policy development. Since the president is situated at the top of the decision-making hierarchy, if he nominates a chancellor who 
supports his ideas, he manages to have an interlocutor to provide him with information and ensures an important actor within the Itamaraty's political game. Moreover, the MER needs to follow superior orders and does not have sufficient power to directly or individually curb the presidential initiatives.

Fifth, among the several decision-making structure models presented by the FPA literature, we consider that the one closest to the administrations in question was the Truman Administration (1945-1953). This decision-making structure may be adequate for moments in FPC. According to George (1988), Truman attempted to weaken the bureaucratic politics by strengthening the role of the heads in each ministry, council or department, by delegating responsibilities to them. This is consistent with the studied cases due to the importance of some people, such as Roberto Campos, Vasco Leitão da Cunha and Juracy Magalhães for Castelo Branco; and Zélia Cardoso, Francisco Rezek, Marcos Azambuja, Marcílio Marques Moreira and Rubens Ricupero for Fernando Collor. Besides, some of these names, such as Juracy, Zélia and Marcílio, occupied more than one important office during the administrations they participated in, which shows their importance for the respective presidents.

In Truman's model, the president sought to hear the opinions and reports of specialists on certain issues and only then emit a decision, centralizing the responsibilities for the decisions taken. These characteristics were also present in both administrations: Castelo Branco would carry out periodic meetings with the SG/CSN, where he would obtain consensus and support for measures that would be taken, and his relations with the US were accompanied by the presence of Juracy Magalhães in the embassy; Collor carried out several meetings with his economic team while at the same time centralizing the responsibilities for personally leading the economic plan.

\section{Final Considerations}

In closing, we will discuss questions left unanswered by our analytical framework and carry out a final assessment.

Initially, what were the main reasons behind the FPC? Besides the already analyzed variables, some complementary factors could also be of influence: a) The regime's survival or legitimacy could be tied to a FPC if the initial objective of the administration was tied to such a need; in these situations, the leader's political costs in promoting change becomes lower to those arising from continuity; b) For the Brazilian case, since the State is the main economic force, the governmental policy is related to the economic field and, therefore, a decision to promote changes in the economic policy will lead to influences in foreign policy; the latter becoming one of the tools so as to achieve the State's objective 
in promoting economic development; c) The FPC can also be a way to distance oneself from the previous administration, a way to present the new regime's intention to promote changes in several spheres, with foreign policy being only one of them.

Secondly, the feedback idea (not discussed within the article, but featured in figure 2). We consider that after a FPC took place in the analyzed administrations, such process occurred. This would be the result of a considerable change in foreign police leading to dissatisfaction in sectors identified with the status quo, which would then act accordingly in order to reestablish the replaced policies. In addition, after a certain period, it becomes possible for the decision-makers to analyze the results of a certain policy, being able to opt for the replacement of practices considered to be inefficient.

During the Castelo Branco Administration, its replacement by Costa e Silva represented the ascension of actors identified with the "hardline" sector. Some sectors advocate that the second military president resumed traces of the IFP and changed the Brazilian stance further from the US (Cervo and Bueno, 2002; Cruz, 2009; Martins, 1975; Pinheiro, 2000).

At the end of the Fernando Collor Administration, Celso Lafer developed a new paradigm for BFP, taking into account the progress achieved during this period, but seeking to resume traditional traits of the MER (Lafer, 1993). The change in the ministry's command is also considered by the literature to be a moment of readjustment (Arbilla, 2000; Mello, 2000; Vieira; 2001).

Lastly, we consider that the literature needs to advance in the analysis of FPC cases for the following reasons: redirection processes, in spite of their emergency characteristic, may have long term effects, becoming the line of action for subsequent long periods of stability. Actions related to FPC have a stronger impact on IS actors since they are marked by a more pronounced behavior by part of the States; and additionally, because they occur during periods of crisis, when the actions of the main actors in foreign policy are more exposed to the public, thus allowing researchers to collect rich information in regards to how decisions are taken. Lastly, we also consider the importance of advancing the development of theoretical frameworks, such as the analytical scheme presented in this article, for developing systematic analyses that allow for better grounded inferences.

Translated by Paulo Scarpa

Submitted in December 2012

Accepted in July 2013 


\section{References}

ALMEIDA, Paulo R. (2008), Do alinhamento recalcitrante à colaboração relutante: o Itamaraty em tempos de AI-5. Rio de Janeiro: Ed. PUC-Rio, Contraponto, pp. 65-89.

ALVAREZ, Mike; CHEIBUB, José A.; LIMONGI, Fernando; PRZERWORSKI, Adam. (2003), ACLP Political and Economic Database. Available at:

<http://www.nd.edu/ apsacp/data.html>

AMORIM, Celso L. N. Celso Amorim (depoimento, 1997). Rio de Janeiro, CPDOC, 2003.

AMORIM NETO, Octávio. (2011), De Dutra a Lula: a condução e os determinantes da política externa brasileira. Rio de Janeiro, Elsevier.

ARBILLA, José. M. (2000), Arranjos Institucionais e Mudança Conceitual nas Políticas Externas Argentina e Brasileira. Contexto Internacional. Rio de Janeiro, vol. 22, $\mathrm{n}^{\mathrm{o}}$ 2, pp. 337-385, julho/dezembro.

ARMIJO, Leslie E. and FAUCHER, Philippe. (2002), 'We Have a Consensus': explaining political support for market reforms in Latin America. Latin American Politics and Society, vol. 44, $\mathrm{n}^{\mathrm{O}} 2$, pp. $1-40$.

AYERBE. Luis F. (1992), A Hegemonia dos Estados Unidos e a trajetória do Desenvolvimento Latino-americano: aspectos políticos e econômicos. 1945-1990. Tese (Doutorado). FFLCH, Universidade de São Paulo, São Paulo.

BATISTA, Paulo N. (1993), A política externa de Collor: modernização ou retrocesso? Política Externa. vol. 1, no 4 , março.

BATISTA, Paulo N. (1994), O Consenso de Washington: a visão neoliberal dos problemas latinoamericanos. Caderno Dívida Externa, nº6.

BRASIL. Constituição (1988), Constituição da República Federativa do Brasil. Brasília, DF, Senado.

CASARÕES, Guilherme S. P. (2011), As Três Camadas da Política Externa do Governo Collor: poder, legitimidade e dissonância. Dissertação (Mestrado) IFCH, Unicamp, Campinas.

CERQUEIRA, Ceres A. (1997), Dívida Externa Brasileira. Processo Negocial: 1983-1996. Brasília: Banco Central do Brasil.

CERVO, Amado L. and BUENO, Clodoaldo. (2002), História da Política Exterior do Brasil. Brasília: Editora Universidade de Brasília.

COLLOR, Fernando. (1990), O Projeto de Reconstrução Nacional. Brasília: Biblioteca da Presidência da República.

COX, Robert W. (1993), Gramsci, Hegemony and International Relations : An Essay in Method. In: Gramsci, Historial materialism and international relations edited by S. Gill. New York: Cambridge University Press. 
CRUZ, Ademar; CAVALCANTE, Antonio R. F.; PEDONE, Luiz. (1993), "Brazil's Foreign Policy under Collor". Journal of Interamerican Studies \& World Affairs, vol. 35, n 1.

CRUZ, Eduardo Lucas de V. (2009), A Política Externa Brasileira no período 1964-1979: o papel do Itamaraty, das Forças Armadas e do Ministério da Fazenda. Dissertação (Mestrado), Faculdade de História, Direito e Serviço Social, UNESP, Franca.

DANESE, Sérgio. (1999), Diplomacia Presidencial: história e crítica. Rio de Janeiro: Topbooks.

DREIFUSS, René. A. (1981), 1964: A conquista do Estado: ação política, poder e golpe de classe. Rio de Janeiro: Vozes.

GARCIA, Eugênio V. (1997), O pensamento dos militares em política internacional (1961-1989). Revista Brasileira de Política Internacional, Brasília, vol. 40, nº1, pp. 18-40.

GEORGE, Alexander (1988), The President and the Management of Foreign Policy: styles and models. In: The Domestic Source of American Foreign Policy - insights and evidence, edited by C. W. Kegley and E. R. Wittkopt. New York: St. Martin's Press, pp. 107-126.

GOLDMANN, Kjell. (1988), Change and Stability in Foreign Policy. The Problems and Possibilities of Détente. Princeton: Princeton University Press.

GUIMARÃES, Feliciano de Sá (2005), A Rodada Uruguai do GATT (1986-1994) e a Política Externa Brasileira: acordos assimétricos, coerção e coalizões. Dissertação (Mestrado). Programa de Pós-graduação San Tiago Dantas, Campinas.

GUSTAVSSON, Jakob. (1999), How Should We Study Foreign Policy Change? Cooperation and Conflict. vol. 34, $\mathrm{n}^{\mathrm{0}}$ 1, pp. 73-95, March.

HAGAN, Joe D. (1989), Domestic Political Regime Changes and Third World Voting Realignments in the United Nations, 1946-84. International Organization, vol. 43, $\mathrm{n}^{\circ}$ 3, pp. 505-541, Summer.

HERMANN, Charles F. (1981), Judgments of Country Specialists about Foreign Policy Formulation: The Operation of Internal Decision Processes. In: Expert-Generated Data: Applications in International Affairs, edited by G. W. Hopple and J A. Kuhlman. Boulder. Colombia: Westview.

HERMANN, Charles F. (1990), Changing Course: When Governments Choose to Redirect Foreign Policy. International Studies Quaterly. vol. 34, $\mathrm{n}^{\circ}$ 1, pp. 3-21, March.

HERMANN, Margaret G.; PRESTON, Thomas; KORANY, Baghat; SHAW, Timothy. M. (2001), Who Leads Matters: The Effects of Powerful Individuals. International Studies Review. vol. 3, $n^{\circ} 2$, pp. 83-131.

HERMANN, Margaret G.; HERMANN, Charles F. (1989), Who Makes Foreign Policy Decisions and How: an empirical inquiry. International Studies Quarterly, vol. 33, n 4 , pp. 361-387, Dec.

HILL, Christopher J. (2003), The Changing Politics of Foreign Policy. New York: Palgrave Macmillan. 
HIRST, Monica and PINHEIRO, Letícia. (1995), A política externa do Brasil em dois tempos. Revista Brasileira de Política Internacional. Brasília, vol. 38, nº 1, pp. 5-23.

HOLSTI, Kalevi J. (1982), Reestructuring Foreign Policy: a neglected phenomenon in Foreign Policy. In: Why Nations Realign: Foreign Policy restructuring in the Postwar World, edited by K, J, Hoslti el al. London: Allen \& Unwin, pp. 1-20.

KLEISTRA, Yvonne and MAYER, Igor. (2001), Stability and Flux in Foreign Affairs: modeling policy and organizational change. Cooperation and Conflict. vol. 36, $\mathrm{n}^{\circ} 4$, pp. 381-414.

LAFER, Celso. (1993), A Política Externa Brasileira no Governo Collor. Política Externa. vol. 1, $\mathrm{n}^{\mathrm{O}} 4$.

LAMARÃO, Alzira Alves de Abreu Sérgio (2007), Personalidades da Política Externa Brasileira. FUNAG, MRE, CPDOC-FGV.

LIMA, Maria Regina de S. (1994), Ejes analíticos y conflicto de paradigmas en la política exterior brasileña. America Latina/Internacional, vol. 1, $\mathrm{n}^{\mathrm{0}} 2$, otoño-invierno.

MARTINS FILHO, João Roberto (1996), O Palácio e a Caserna: A Dinâmica Militar das Crises Políticas na Ditadura (1964-1969). São Carlos: Editora da UFSCar.

MARTINS, Carlos Estevam. (1975a), A Evolução da Política externa Brasileira da década 64/74. Estudos Cebrap. $\mathrm{n}^{\mathrm{O}} 12$.

MARTINS, Carlos Estevam (1975b), Cadernos Cebrap no 9: Brasil - Estados Unidos: dos 60 aos 70. CEBRAP, Editora Brasiliense, São Paulo.

MELLO, Flavia C. (2000), Regionalismo e Inserção Internacional: continuidade e transformação da Política Externa Brasileira nos anos 90. Tese (Doutorado). Departamento de Ciência Política, Universidade de São Paulo, São Paulo.

MIYAMOTO, Shiguenoli and GONÇALVES, Williams S. (1993), Os Militares na Política Externa Brasileira: 1964-1984. Estudos Históricos, Rio de Janeiro, vol. 6, n 12, pp. 211-246.

MRE (1966), A Política Exterior da Revolução Brasileira. Brasília: Seção de Publicações.

MRE (1990), Resenha de Política Exterior do Brasil. nº 64 a 67, ano 16. Brasília: MRE.

MRE (1992), Resenha de Política Exterior do Brasil. nº 70, ano 18. Brasília: MRE.

NIKLASSON, Tomas. (2006), Regime Stability and Foreign Policy Change: interaction between domestic and foreign policy in Hungary, 1956-1994. Lund: Lunds Universitet.

PAPADAKIS, Maria; STARR, Harvey. (1987), "Opportunity, Willingness, and Small States: the relationship between environment and Foreign Policy", In New Directions in the Study of Foreign Policy, edited by C. F. Hermann, C. W. Kegley and J. Rosenau. Boston: Allen and Unwin.

PINHEIRO, Letícia. (2000), Traídos pelo Desejo: um ensaio sobre a teoria e a prática da política externa brasileira contemporânea. Contexto Internacional. Rio de Janeiro, vol. 22, pp. 305335.

PINHEIRO, Letícia. (2004), Política Externa Brasileira, 1889-2002. Rio de Janeiro: Zahar. 
PINHEIRO, Letícia; SALOMON, Mônica (2011). Análise de Política Externa e Política Externa Brasileira: trajetória, desafios e possibilidades de um campo de estudos. Paper apresentado no $3^{\circ}$ Congresso da ABRI, São Paulo: USP, monografia.

PRADO, Débora F. B. and MIYAMOTO, Shiguenoli. (2010), A Política Externa do Governo José Sarney (1985 - 1990). Revista de Economia e Relações Internacionais, vol. 8, n 16, pp. $67-80$.

REIS, Eustáquio et al. (2003), Contas Nacionais. Brasil: Tabela População, Produto Interno Bruto, Produto Interno Bruto - per capita - e deflator implícito do Produto Interno Bruto, 1901/2000, In: Estatísticas do Século XX. Rio de Janeiro: IBGE, 2007.

ROSATI, Jerel A. (1994), Cycles in Foreign Policy Restructuring: the politics of continuity and change in U.S. foreign policy. In: Foreign Policy Restructuring: how governments respond to Global Change edited by J. A. Rosati, M. W. Sampson and J. D. Hagan. Columbia: University of South Carolina Press.

ROSATI, Jerel A.; SAMPSON, Martin W.; HAGAN, Joe D. (1994), The Study of Change in Foreign Policy, In: Foreign Policy Restructuring: how governments respond to Global Change, edited by J. A. Rosati, M. W. Sampson and J. D. Hagan. Columbia: University of South Carolina Press.

RYNNING, Sten and GUZZINI, Stefano. (2001), Realism and Foreign Policy Analysis. Working Papers 42. Copenhagen Peace Research Institute.

SARAIVA, José F. S. (2003), Is it possible to establish a causal nexus between foreign policy and political regime. In: Foreign policy and political regime, edited by J. S. Saraiva. Brasília: Instituto Brasileiro de Relações Internacionais.

SARTORI, Giovanni (1994), Compare why and how, comparing, miscomparing and the comparative method. In: Comparing Nations: concepts, strategies, substance, edited by M. Dogan and A. Kazancigil. Oxford: Blackwell Publishers, pp. 14-34.

SIMÕES, Gustavo da F. (2010), Turbulência, política interna e política externa durante o Governo Castelo Branco (1964-1967). Dissertação (Mestrado), Instituto de Relações Internacionais, UnB, Brasília.

VAN EVERA, Stephen. (1997), Guide to Methods for Students of Political Science. Ithaca, Cornell University Press.

VIANA Filho, L. (1975), O Governo Castelo Branco. Tomo II. Rio de Janeiro: José Olympio.

VIEIRA, Marco Antonio M. C. (2001) Ideias e Instituições: uma reflexão sobre a política externa brasileira do início da década de 90. Contexto Internacional, vol. 23, n. 2, p. 245-293.

VIZENTINI, Paulo F. (1998), A política externa do regime militar brasileiro: multilateralização, desenvolvimento e construção de uma potência média (1964-1985). Porto Alegre: UFRGS.

VIZENTINI, Paulo F. (2008), Relações Internacionais do Brasil: de Vargas a Lula - $3^{\text {a }}$ Ed. São Paulo: Fundação Perseu Abramo.

VOLGY, Thomas J. and SCHWARZ, John E. (1994), Foreign Policy Restructuring and the Myriad Webs of Restraint. In: Foreign Policy Restructuring: how governments respond to Global 
Change edited by J. A. Rosati, M. W. Sampson and J. D. Hagan. Columbia: University of South Carolina Press.

WORLD BANK. World Development Indicators (WDI) \& Global Development Finance (GDF). Available at: < http://databank.worldbank.org/ddp/home.do>

WORLD TRADE ORGANIZATION. Understanding the WTO: The Uruguay Round. Available at: <http://www.wto.org/english/thewto_e/whatis_e/tif_e/fact5_e.htm> 